\title{
ANALISIS STRATEGI PEMASARAN DALAM MENGHADAPI PERSAINGAN ANTAR JASA PENGINAPAN DI KOTA LAMONGAN (STUDI PADA HOTEL MAHKOTA LAMONGAN)
}

\author{
Hery Suprapto \\ Prodi Manajemen, Fakultas Ekonomi, Universitas Islam Lamongan \\ Jl. Veteran No. 53A Lamongan \\ Telp. (0322) 324706, Faks. (0322) 324706 \\ Herysuprapto20@gmail.com
}

\begin{abstract}
ABSTRAK
Mengetahui strategi pemasaran hotel untuk memajukan jasa penginapan pada hotel Mahkota. Penelitian ini bertujuan untuk Faktor-Faktor internal (kekuatan dan kelemahan) dan faktor eksternal (peluang dan ancaman) terutama dari sisi strategi pemasarannya dan untuk mengetahui efektifitas strategi pemasaran yang sudah dilakukan Hotel Mahkota. Metode dalam penelitian ini adalah metode kualitatif, dengan menggunakan analisis strategi yaitu analisis internal dan analisis external dengan menggunakan metode analisis SWOT. Berdasarkan hasil perhitungan, faktor internal kekuatan yang dimiliki Hotel Mahkota lebih besar dari faktor kelemahannya yaitu sebesar 2,16 dan untuk faktor eksternal peluang juga lebih besar dari faktor eksternal ancamannya yaitu sebesar 2,22 dari perhitungan tersebut dapat ditentukan posisi Hotel Mahkota sehingga diperoleh formulasi strategi pemasaran yang sesuai. Dengan adanya penelitian ini, diharapkan memberikan pelayanan yang lebih baik bagi konsumen kedepannya.
\end{abstract}

Kata Kunci : strategi pemasaran, analisis SWOT, matriks SWOT, matriks internal dan eksternal

\section{PENDAHULUAN}

Saat ini di kota Lamongan semakin banyak bermunculan usahausaha jasa yang bergerak di berbagai bidang, khususnya untuk usaha perhotelan. Hal ini dapat di lihat dari semakin banyaknya produsen yang terlibat dalam pemenuhan kebutuhan yang diinginkan konsumen, menyebabkan setiap perusahaan harus mampu menempatkan orientasi perusahaan jasa untuk meningkatkan kepuasan konsumen sebagai tujuan utama. Perusahaan harus dapat memberikan kepuasan kepada pelanggan barang atau jasa yang mempunyai nilai lebih tinggi dengan mutu lebih baik dan harga lebih terjangkau, fasilitas yang memadai serta pelayanan yang lebih baik dari pada pesaing lainnya.

Perusahaan dalam menjalankan usahanya harus selalu mengamati perubahan perilaku konsumen sehingga dapat mengantisipasi perusahaan perilaku tersebut, untuk kemudian dijadikan kajian dalam rangka untuk 
memperbaiki strategi pemasarannya.

Pada hakekatnya tujuan dari pemasaran adalah untuk mengetahui dan memahami sifat konsumen sehingga produk yang ditawarkan laku terjual.

Industri perhotelan adalah industri jasa yang memadukan antara produk dan layanan. Desain bangunan, interior dan eksterior kamar hotel serta restoran, suasana yang tercipta di kamar hotel, restoran serta makanan dan minuman yang di jual beserta keseluruhan fasilitas yang ada merupakan contoh produk yang di jual. Sedangkan layanan yang di jual adalah keramah tamahan dan ketrampilan staf atau karyawan hotel dalam melayani pelanggan. (Jurnal Ilmu \& Riset Manajemen Vol. 3 No. 12 (2014)

\section{Menurut Christoper $\mathrm{H}$.} Lovelock, definisi jasa adalah bahwa jasa itu lebih merupakan penampilaan kerja disbanding sebagai suatu benda, dan karena jasa merupakan sesuatu yang tidak terwujud maka jasa hanyalah disarankan dan dialami bukan dimiliki. (Excellent Hotel Operation 2016, hal 88)
Fungsi hotel pada zaman dahulu hanya sebagai tempat bermalam bagi konsumen yang melakukan perjalanan bisnis atau wisata dan tidak memiliki relasi di tempat tujuan. Namun seiring berjalannya waktu fungsi hotel mengalami peningkatan. Hal ini memacu manajemen hotel untuk semakin meningkatkan kulitas hotel untuk memperoleh konsumen sebanyak-banyaknnya.

\section{KAJIAN PUSTAKA}

\section{Pengertian Strategi}

Menurut Johnson dan schools (2016:29) strategi adalah arah dan ruang lingkup sebuah organisasi dalam jangka panjang yang mencapai keuntungan bagi organisasi melalui konfigurasi sumber daya dalam lingkungan yang menantang untuk memenuhi kebutuhan pasar dan memenuhi harapan pemangku kepentingan.

Menurut Siagian (2016:29) juga menyatakan strategi adalah seraingkaian keputusan dan tindakan mendasar yang dibuat oleh manajemen puncak dan diimplementasikan oleh seluruh jajaran organisasi dalam rangka mencapai tujuan organisasi tersebut. 


\section{Pengertian Pemasaran}

Menurut Kotler dan Amstrong (2014:27) pemasaran adalah proses dimana perusahaan menciptakan nilai bagi pelanggan dan membangun hubungan yang kuat dengan pelanggan, dengan tujuan menangkap nilai dari pelanggan sebagai imbalannya.

Menurut Sunyoto (2014:18) pemasaran adalah merupakan ujung tombak perusahaan dalam dunia persaingan yang semakin erat, perusahaan dituntut agar tetap bertahan hidup dan berkembang.

\section{Pemasaran Jasa}

Industri jasa pada saat ini merupakan sektor ekonomi yang sangat besar dari pertumbuhannyapun sangat pesat, pertumbuhan tersebut selain diakibatkan oleh pertumbuhan jenis jasa yang sudah ada sebelumnya, juga disebabkan oleh munculnya jenis jasa baru, sebagai akibat dari tuntutan dan perkembangan zaman. Di pandang dari segi konteks globalisasi, pesatnya pertumbuhan bisnis jasa antar Negara ditandai dengan meningkatnya intensitas pemasaran lintas Negara serta terjadinya aliansi berbagai penyedia jasa di dunia.

\section{Perkembangan tersebut pada} akhirnya mampu memberikan tekanan yang kuat terhadap perombakan regulasi, khususnya pengunduran proteksi dan pemanfaatan teknologi baru yang secara langsung akan berdampak pada menguatnya kompetisi dalam industri. Kondisi ini secara langsung menghadapkan para pelaku bisnis kepada permasalahan persaingan usaha yang semakin tinggi. Mereka dituntut untuk mampu mengidentifikasi bentuk persaingan yang akan dihadapi, menetapkan berbagai strandart kinerjanya serta mengenali secara baik para pesaingnya (Hurriyati, 2014:41).

\section{Pengertian Jasa}

Menurut Fandy Tjiptono (2014:26) jasa merupakan sebagai setiap tindakan atau perbuatan yang dapat ditawarkan oleh suatu pihak lain yang pada dasarnya yang bersifat intangible (tidak berwujud fisik) dan tidak menghasilkan kepemilikan sesuatu. Menurut Tjiptono dan Chandra (2016:20) jasa merupakan 
aktifitas, manfaat atau kepuasan yang ditawarkan untuk dijual.

Kemudian menurut Gronross dalam Tjiptono dan candra (2016:29) jasa adalah proses yang terdiri dari serangkaian aktivitas intangible yang biasanya (namun tidak harus selalu) terjadi pada interaksi antara pelanggan dan karyawan jasa atau sumber daya fisik atau barang atau sistem penyedia jasa, yang disediakan sebagai solusi atas masalah pelanggan.

\section{Karakteristik Jasa}

Menurut Lovelock dan Gummesson dalam Tjiptono dan Chandra, (2016:39) menyebutkan karakteristik jasa sebagai berikut:

a. Intangibility (tidak berwujud) Jasa tidak dapat dilihat, dirasa, dicium, didengar, atau di raba sebelum dibeli atau di konsumsi. Seorang konsumen tidak dapat menilai hasil dari sebuah jasa sebelum ia mengalami atau mengkonsumsinya sendiri, bila pelanggan membeli jasa tertentu, maka ia hanya menggunakan, memanfaatkan, atau menyewa jasa tersebut.

b. Heterogeneity (bervariasi) Jasa bersifat variabel karena merupakan non-standarlized output, artinya terdapat variasi berbentuk, kualitas dan jenis, tergantung pada siapa, kapan, dan dimana jasa tersebut diproduksi.

c. Inseparability (tidak dapat dipisahkan) Jasa umumnya dijual terlebih dahulu, baru kemudian di produksi dan dikonsumsi pada waktu dan tempat yang sama. Dalam interaksinya konsumen selalu menunggu sampai jasa tersebut di produksi, maka interaksi antara penyedia jasa dan pelanggan merupakan cirri khusus dalam pemasaran jasa.

d. Perisability (tidak tahan lama) Jasa merupakan komoditas yang tidak tahan lama, tidak dapat disimpan untuk pemakaian ulang diwaktu dating, dijual kembali, atau dikembalikan, namun tidak masalah bila permintaan tetap.

\section{Bauran Pemasaran Jasa}

Menurut Kotler dan Keller (2014:75) bauran pemasaran adalah seperangkat alat pemasaran yang digunakan perusahaan untuk terus menerus mencapai tujuan pemasarannya di pasar sasaran. 
Unsur bauran pemasaran dapat digolongkan dalam empat kelompok didefinisikan oleh Kotler dan Armstrong (2014:76) sebagai berikut:

1. Produk : adalah kombinasi barang atau jasa perusahaan menawarkan dua target pasar.

2. Harga : adalah jumlah pelanggan harus dibayar untuk memperoleh produk.

3. Tempat : adalah mencakup perusahaan produk tersedia untuk menagertkan pelanggan.

4. Promosi : adalah mengacu pada kegiatan berkomunikasi kebaikan produk dan membujuk pelanggan sasaran.

\section{Jenis Dan Klasifikasi Dalam Industri Perhotelan}

Hotel adalah suatu bentuk akomodasi yang dikelola secara komersial, disediakan bagi setiap orang untuk memperoleh pelayanan penginapan, makanan dan minuman (SK. Menhub.RI. No. PM 10/PW.391/Phb-77).

Hotel merupakan salah satu komponen industri pariwisata. Di mana cirri dari industry pariwisata adalah usaha dalam bidang jasa yang memberikan pelayanan kepada tamu sehingga tamu merasa puas akan kebutuhan dan keinginannya. Definisi lain tentang pariwisata, terdapat dalam Undang-Undang No. 10/2009 tentang kepariwisataan, dimana yang dimaksud pariwisata adalah berbagai macam kegiatan wisata yang didukung oleh berbagai fasilitas serta layanan yang disediakan masyarakat, pengusaha, dan pemerintah daerah. Hotel merupakan organisasi kompleks dengan beberapa bagian yang mungkin tidak akan terlihat oleh masyarakat. Dalam menghadapi persaingan yang terjadi, untuk dapat beroprasi secara efektif dan efisien berbagai upaya dilakukan oleh masing-masing hotelsalah satunya yaitu peningkatan kualitas pelayanan yang berorientasi pada kepuasan konsumen oleh setiap bagian yang ada dihotel Komar, (2014:20).

\section{Analisis Swot}

Menurut Freddy Rangkuti (2014:197-203), analisis SWOT adalah Suatu cara untuk mengidentifikasi berbagai faktor secara sistemstis dalam rangka merumuskan strategi perusahaan. Analisis ini didasarkan pada logika dapat memaksimalkan kekuatan dan 
peluang, namun secara bersamaan dapat meminimalkan kelemahan dan ancaman. Analisis SWOT mempertimbangkan faktor lingkungan eksternal peluang dan ancaman yang dihadapi dunia bisnis serta lingkungan internal kekuatan dan kelemahan. Analisis SWOT membandingkan antara faktor eksternal peluang dan ancaman dengan faktor internal kekuatan dan kelemahan sehingga dari analisis tersebut dapat diambil suatu keputusan strategis suatu organisasi.

Menurut Irham Fahmi (2015:60) untuk menganalisis secara lebih dalam tentang SWOT, maka perlu diketahui faktor eksternal dan faktor internal sebagai bagian penting dalam analisis SWOT, yaitu:

a. Faktor eksternal Faktor ini mempengaruhi terbentuknya opportunities and thteats $(\mathrm{O}$ dan T). Dimana faktor ini berhubungan dengan kondisikondisi yang terjadi diluar perusahaan dan mempengaruhi dalam pembuatan keputusan perusahaan.Faktor ini meliputi lingkungan industri dan lingkungan bisnis makro, ekonomi, politik, hukum, teknologi, kependudukan dan sosial budaya.

b. Faktor Internal Faktor ini mempengaruhi terbentuknya Strengths and Weaknesses (S dan W). Dimana faktor ini berhubungan dengan kondisi yang terjadi dalam perusahaan,yang mana ini turut mempengaruhi terbentuknya pembuatan keputusan dalam perusahaan. Faktor internal ini meliputi semua ancaman manajemen fungsional: Pemasaran, keuangan, operasi, umber daya manusia, penelitihan dan pengembangan, sistem informasi manajemen dan budaya perusahaan.

\section{Model Analisis SWOT}

Analisis

SWOT

Membandingkan antara faktor eksternal peluang dan ancaman dengan faktor internal kekuatan dan kelemahan. Faktor internal di masukkan ke dalam matrik yang disebut dengan matrik faktor strategi internal atau IFAS (Internal Factor Analisis Summary). Faktor eksternal di masukkan ke dalam matrik yang disebut Matrik faktor strategi eksternal atau EFAS (Eksternal 
Factor Anlisis Summary). Setelah matrik faktor strategi internal dan eksternal selesai disusun, kemudian hasilnya di masukkan dalam model kuantitatif, yaitu matrik SWOT

\section{Matrik SWOT}

Alat yang dipakai untuk menyusun faktor-faktor strategis perusahaan adalah matrik SWOT. Matriks ini dapat menggambarkan secara jelas bagaimana peluang dan ancaman eksternal yang dihadapi perusahaan dapat disesuaikan dengan kekuatan dan kelamahan yang dimilikinya. Matriks ini dapat menghasilkan empat set kemungkinan alternatif strategis.

\section{METODE PENELITIAN}

Dalam penelitian ini penulis mengunakan jenis penelitian deskriptif kualitatif yaitu jenis penelitian yang diperoleh dalam bentuk informasi lisan dan tulisan, yang meliputi sejarah berdirinya perusahaan, struktur organisasi sertatugas dari masing-masing bagian dalam perusahaan. Menurut Sugiono (2016:38), yang dimaksud data kualitatif adalah data yang berupa kalimat-kalimat yang mendalam yang berasal dari informan dan perilaku yang diamati. Teknik yang digunakan dalam penelitian kualitatif pada umumnya yaitu metode wawancara dan observasi.

\section{Menurut Sugiyono (2016:62)} mengartikan bahwa sampel adalah bagian dari jumlah dan karakteristik yang dimiliki populasi. Sampel dalam hal ini adalah pihak internal (manajer) adalah orang yang ahli dalam bidang strategi perusahaan yaitu: Marketing Communication Manager dan Senior Human Resources Office. Dan ditambahkan dengan data pendukung dari beberapa pihak eksternal (konsumen) Hotel Mahkota Lamongan yaitu empat konsumen. Jadi total responden dalam Penelitian ini sebanyak 6 orang.

$$
\text { Populasi adalah wilayah }
$$
generalisasi yang terdiri atas obyek atau subyek yang mempunyai kualitas dan karakteristik tertentu yang diterapkan oleh peneliti untuk dipelajari dan kemudian ditarik kesimpulannya Sugiono, (2016:61). Populasi meliputi seluruh karakteristik atau sifat yang dimiliki oleh subyek atau obyek yang diteliti. Populasi dalam penelitian ini adalah 
seluruh pihak yang berhubungan dengan kelangsungan ke arah lebih maju Hotel Mahkota Lamongan.

\section{HASIL DAN PEMBAHASAN}

\section{Analisis Deskriptif}

\section{Hotel Mahkota Lamongan} adalah Hotel yang bergerak di bidang penyediaan jasa kamar Hotel, kegiatan pertemuan dan tempat resepsi pernikahan.Sebagai perusahaan yang bergerak dalam bisnis perhotelan dan pengelola jasa penyewaan ruangan resepsi perkawinan maka kegiatan pemasaran menjadi faktor yang paling penting peranannya dalam upaya pencapaian peningkatan jumlah kamar yang terpakai dan peningkatan penggunaan convention hall untuk resepsi pernikahan. Kondisi pasar yang semakin mengarah pada persaingan penjualan kamar Hotel dan penggunaan convention hall menjadi kendala tersendiri bagi Hotel Mahkota untuk mengantisispasi persaingan pasar tersebut maka Hotel Mahkota menetapkan strategi pemasaran yang berorientasi pada peningkatan penjualan serta segmentasi pasar dalam negeri.
Untuk

menganalisa pemasaran jasa Hotel konsep yang dianggap efektif adalah dengan menggunakan konsep Marketing Mix P7, yaitu :

\section{Product}

Uraian produk berdasarkan hasil wawancara dengan Rusdi Afandi yang merupakan General Manajer tentang produk yang dimiliki Hotel Mahkota Lamongan dideskripsikan sebagai berikut :

Kamar-kamar di Hotel Mahkota berukuran luas dan nyaman. Terdapat jendela-jendela berukuran besar di setiap kamar, sehingga tamu dapat menikmati pemandangan kota dengan leluasa. Kamar-kamar ber AC tersebut dikelompokkan menjadi beberapa tipe, antara lain Executive Room, Suite Room, Junior Suite Room, Deluxe Room dan Standart Room. Semuanya dilengkapi kamar mandi dengan shower, perabot didalam kamar tertata rapi.Selain tempat tidur, fasilitas yang tersedia meliputi meja tulis beserta kursi, televisi, wifi, dan perlengkapan mandi.

2. Price

Hotel Mahkota sebagai salah satu Hotel yang ada di Lamongan selalu 
mengeluarkan berbagai promo pada setiap momen tertentu untuk mengeluarkan launching promo, seperti tahun baru, makan malam, valentine, atau melihat keadaan weekend yang sedang sepi, maka pihak Hotel akan membuat promo, jadi Hotel selalu melihat peluangpeluang di pasar, dan pada saat pasar sedang ramai maka pihak Hotel mengeluarkan promo dan itu merupakan strategi harga dari Hotel Mahkota Lamongan.

3. Promotion

Rusdi Afandi mengemukakan bentuk-bentuk promosi pemasaran yang dilakukan oleh Hotel Mahkota dalam meningkatkan jumlah pelanggannya, yaitu dengan melakukan kegiatan periklanan. Adapun kegiatan periklanan yang dilakukan Hotel Mahkota dengan berbagai macam cara diantaranya melalui media social, elektronik.

\section{Place}

Hotel Mahkota Lamongan terletak di tengah kota yang sedang berkembang pesat di kota Lamongan tepatnya di Jln. Sunan Drajat No. 06 Lamongan, akses ke berbagai tempat cukup mudah mulai dari dekat dengan alun-alun hingga pasar.

\section{People}

Hotel Mahkota adalah Hotel yang selalu menjaga eksistensi pelayanan yang High Quality. Melalui pelayanan yang baik, cepat, ramah, teliti dan akurat maka dapat menciptakan kepuasan dan kesetiaan pelanggan terhadap perusahaan yang akhirnya akan meningkatkan nama baik Hotel Mahkota Lamongan.

6. Physical Evidence

Hotel Mahkota Lamongan merupakan akomodasi mewah yang letaknya di jantung kota. Menampilkan pelayanan yang baik dan memuaskan, Hotel Mahkota menawarkan kamar yang luas dengan fasilitas yang memadai.Kamar-kamar di Hotel ini juga sangat nyaman, sehingga tamu dapat merasakan kenyamanan saat berada di kamar.

\section{Process}

Jasa pelengap tersebut adalah keramahan, pengamanan penerimaan pesanan dan semuanya ini dilaksanakan oleh Hotel Mahkota dalam hal penerimaan pesanan, maka proses pemesanan kamar hotel atau booking untuk resepsi perkawinan dan fasilitas lainnya bisa langsung menghubungi resepsionis Hotel 
Mahkota Lamongan melalui telepon.

/ Fax :0322321060 yang berada di Jln. Sunan Drajad No. 4-8 Lamongan.

\section{Analisis SWOT Hotel Mahkota}

\section{Lamongan}

Analisis SWOT adalah identifikasi berbagai faktor secara sistematis untuk merumuskan strategi pemasaran pada Hotel Mahkota. Analisis ini di dasarkan pada logika yang dapat memaksimalkan kekuatan (strength) dan peluang (opportunities), namun secara bersamaan dapat meminimalkan kelemahan (weaknes) dan ancaman (threat), model yang dipakai pada tahap ini terdiri dari matriks faktor strategi internal dan matriks faktor strategi eksternal.

Berdasarkan hasil perhitungan, faktor internal kekuatan yang dimiliki Hotel Mahkota lebih besar dari faktor kelemahannya yaitu sebesar 2,16 dan untuk faktor eksternal peluang juga lebih besar dari faktor eksternal ancamannya yaitu sebesar 2,22 dari perhitungan tersebut dapat ditentukan posisi Hotel Mahkota sehingga diperoleh formulasi strategi pemasaran yang sesuai.

\section{Matrik SWOT}

Matrik SWOT merupakan matrik yang disusun dengan menggunakan variabel-variabel kekuatan, kelemahan, peluang, dan ancaman yang diidentifikasi dalam faktor-faktor strategis internal dan faktor strategi eksternal.Matrik SWOT ini menggambarkan bagaimana peluang dan ancaman dari lingkungan eksternal perusahaan dapat disesuaikan dengan kekuatan dan kelemahan yang dimiliki perusahaan.Analisis dengan menggunakan model matrik SWOT ini menggunakan data yang diperoleh dari tabel Faktor Strategi Internal Dan Faktor Strategi Eksternal Hotel Mahkota Lamongan.

\section{KESIMPULAN}

Dari hasil identifikasi faktor strategi intenal dan faktor strategi eksternal maka Hotel Mahkota Lamongan memiliki posisi kompetitif pasar yang kuat dalam industri yang aktraktif. diketahui posisi dan profil lingkungan internal dan eksternal, Hotel Mahkota Hal ini menunjukkan Hotel Mahkota Lamongan harus tetap melakukan upaya-upaya meningkatkan kualitas 
produk, fasilitas-fasilitas, pelayanan dan distribusi produk. Secara keseluruhan Hotel Mahkota Lamongan saat ini merupakan perusahaan yang cukup sukses dalam industri perhotelan terutama hotel berbintang.

Hotel Mahkota Lamongan didukung oleh kekuatan internal yang cukup baik, seperti fasilitasfasilitas yang lengkap, kualitas produk yang baik, dan pelayanan yang setara dengan hotel-hotel lainnya, dukungan sumber daya yang prefesional, dan dukungan manajemen yang baik. Terdapat empat alternatif strategi yang dapat diterapkan Hotel Mahkota Lamongan sehubungan dengan perkembangan bisnis dan perubahan kondisi pasar yang tersedia berdasarkan faktiorfaktor internal dan faktor-faktor Hotel Mahkota Lamongan. Dari empat strategi tersebut Strength and Opportunity,Weaknes and Oopportunity,Strength and Threat, Weaknes and Threat digunakan untuk diterapkan dalam pengembangan strategi yang dapat disarankan pada manajemen Hotel Mahkota Lamongan.

\section{DAFTAR PUSTAKA}

Dwi Fitriana Dewi. 2014. Dengan Judul Skripsi "Analisis Strategi Pemasaran Perhotelan Di Makassar (Studi Pada Grand Clarion Hotel \& Convention)". Universitas Hasanuddin

Makassar.

Dimas Hendika Wibowo, Zainul Arifin, Sunarti. 2015. Analisis Strategi Pemasaran Untuk Meningkatkan Daya Saing UMKM (Studi Pada Batik Diajeng Solo). Jurnal Administrasi Bisnis. Vol 29, 1 Desember 2015.

Kotler, Philip Dan Amstrong Gary. 2014. Principles Of Marketing. 12 $^{\text {th }}$ Edition, Jakarta : Erlangga. Siagian Sondang P. 2014. Manajemen Sumber Daya Manusia. Jakarta : Bumi Aksara.

Sunyoto Danang. 2014. Konsep Dasar Riset Pemasaran Dan Perilaku Konsumen . Yogyakarta:CAPS.

Hurriyatih Ratih. 2014. Bauran

Pemasaran Dan Loyalitas Konsumen. Edisi 5. Bandung : Alfabetha. 
Anggraini Marcos Dan Ronny $\mathrm{H}$.

Mustamu. 2014. Perumusan

Strategi Bersaing Salah Satu

Hotel Bintang Tiga

Samarinda. Jurnal AGORA.

Vol 2. No.1 2014.

Okto Widhiarsa. 2011. Dengan Judul

Skripsi "Analisis Tingkat

Kepuasan Konsumen Terhadap

Kulitas Pelayanan Hotel

Semarang". Universitas

Diponegoro.

Tjiptono Fandy. 2014. Pemasaran

Jasa (Prinsip, Penerapan,

Penelitian). Yogyakarta : Andi.

Tjiptono Fandy Dan Gregorius

Candra. 2016. Service, Quality,

Dan Satisfaction, Edisi 4.

Yogyakarta : Andi.

Philip Kotler Dan Kevin Lane

Keller. 2015. Manajemen

Pemasaran. Edisi 13. Jakarta :

Erlangga.
Lumpiyo Rambat. 2013. Manajemen

Pemasaran Jasa. Edisi 3.

Jakarta : Salemba.

Bagyono. 2014. Pariwisata Dan

Perhotelan. Edisi 4. Bandung :

Alfabetha.

Http://Www.Academia.Edu/2913426

3/Skripsi Analisis Strategi

Pemasaran Perhotelan Di

Makassar Studi Kasus Di Grand

Clarion Hotel And

Conventional. Di Akses Tanggal

(10 Desember 2018).

Fahmi, Irham. 2015. Pengantar Manajemen Keungan Teori

Dan Soal. Bandung : Gramedia. Rangkuti Freddy. 2017. Customer

Care Excellent (Meningkatkan Kinerja Perusahaan Melalui Pelayanan Prima). Jakarta : Gramedia. 